\title{
Population Mental Health during the COVID-19 Pandemic: Experiences from a Drive-thru Testing Center
}

\author{
Kenneth Andrew Hoekstra
}

\section{Kenneth A Hoekstra}

Quest Diagnostics, C/o Peace Health

United General Medical Center, SedroWooley, WA, USA.

\section{Correspondence}

Dr. Kenneth A Hoekstra

Quest Diagnostics, C/o Peace Health

United General Medical Center,

Sedro-Wooley, WA, USA.

Mobile no: +1-360-856-7696

Email: khoekstra2@peacehealth.org

History

- Submission Date: 03-04-2021;

- Revised Date: 03-05-2021;

- Accepted Date: 13-06-2021;

DOI : 10.5530/ijmedph.2021.3.31

Article Available online

http://www.ijmedph.org/v11/i3

\section{Copyright}

(C) 2021 Phcog.Net. This is an openaccess article distributed under the terms of the Creative Commons Attribution 4.0 International license.

\begin{abstract}
Aim/Background: Public health has a unique opportunity to connect with the psychology of the population during the COVID-19 pandemic. Materials and Methods: Beginning May 2020 and ending March 12, 2021, the Skagit County Health Department provided a drivethru COVID-19 testing center during the weekdays for community members and healthcare workers. Test results were typically returned in 1-3 days. Results: The drive-thru COVID-19 testing model provided the healthcare worker the opportunity to consult with individuals presenting for COVID-19 testing. Public health listened closely, answered the public's questions and provided additional healthcare information when needed and requested. Conclusion: Throughout the COVID-19 pandemic, COVID-19 drive-thru testing centers have emerged world-wide. For healthcare and public health workers, these centers have allowed for additional conversation on topics related to community mental health.

Key words: COVID-19, Psychological, Stress, Testing, Drive-thru.
\end{abstract}

Since the beginning of the COVID-19 pandemic, there has been an increasing concern with the psychology of the population. Recent reports have highlighted the fragility of psychological resilience among patients and healthcare workers. ${ }^{1,2}$ However, less attention has been directed towards the behavior and psychological status of the general public throughout this pandemic. ${ }^{3}$

Thousands of community-based testing sites including drive-thru testing centers continue to operate across Asia, the UK, and North America. While some testing sites are restricted to high-risk populations, others have worked with public health and local laboratories to provide testing to anyone requiring a molecular COVID-19 test.

Our population is beginning to understand there is no immediate cure for COVID-19. As a volunteer at a COVID-19 drive-thru testing center, we aim to provide reassurance in time of doubt and uncertainty. It is viewed as a lifeline for testing and information about the disease. The COVID-19 drive-thru may provide community members with their only connection to healthcare services and providers. People who come through are nervous, anxious and scared. Some already have poor physical and mental health. They are constantly bombarded by social media reports of rising case counts and death rates. They want someone to talk to, someone to hear them, to say it is going to be $\mathrm{OK}$ and perhaps to gain some small control over an unseeingly uncontrollable pandemic. ${ }^{4}$ Some drive-thru patients believe they may have the virus and have unknowingly spread it to others at family gatherings. They bring their children who require a negative test prior to returning to school or other necessary activities. Many are under financial stress and worried about the future. They are concerned they may not be able to work if they become infected. Still others have not been working and are under strict self-isolation, masking and staying home by themselves orders due to a COVID-19 diagnosis or direct/indirect contact with a known COVID-19 individual.

COVID-19 drive-thru testing centers provide a unique opportunity for healthcare professionals to connect with the general public's mental health. Talking calmly through a crack in a vehicle window dressed in personal protective equipment is not very personal. Yet, we have adapted by speaking loudly, using inviting body gestures to communicate, all while explaining what the test is and how together we are going to collect it. After speaking with many patients, I teach they are terrified of getting sick or infecting others. I respectfully answer their questions and praise the children who often come as well, for being brave crusaders in this war against an infectious agent. "Like a superhero" I say. "Let's help each other and save the planet. "Just before they drive away, I place a gloved touch to a close window to confirm that together we will get through this.

While a moderate level of anxiety can help maintain perspective, the general population has come to realize how little they control their lives. Many of the current pandemic events are outside of their control. People emerge physically and spiritually fatigued. I believe our COVID-19 drive-thru testing centers remain important public health work that can be done right now. Our population deserves to be heard and cared for. We can put aside hardships of inequality

Cite this article : Hoekstra KA. Population Mental Health during the COVID-19 Pandemic: Experiences from a Drive-thru Testing Center. Int. J. Med. Public Health. 2021;11(3):168-9. 
and social isolation that often keep us siloed, and briefly connect with their deeper psychological needs to COVID-19. ${ }^{2}$ Population mental health and wellness has become a key focus for many COVID-19 drivethru sites. A shift in the urgency to acknowledge the mental health needs of our population cannot be understated.

\section{ACKNOWLEDGEMENT}

Thank you to the Skagit County Public Health Department for providing the drive-thru COVID-19 testing center for the community.

\section{CONFLICT OF INTEREST}

The author declares that there is no conflict of interest.

\section{REFERENCES}

1. Ma YF, Li W, Deng HB, Wang L, Wang Y, Wang PH, et al. Prevalence of depression and its association with quality of life in clinically stable patients with $\mathrm{CO}$ VID-19. J Affect Disord. 2020;275:145-8.

2. Moreno C, Wykes T, Galderisi S, Nordentoft M, Crossley N, Jones N, et al. How mental Health care should change as a consequence of the COVID-19 pandemic. Lancet Psychiatry 2020;7:813-24.

3. Li J, Yang Z, Qiu H, Wang Y, Jian L, Ji J, et al. Anxiety and depression among general Population in China at the peak of the COVID-19 epidemic. World Psychiatry 2020;19(2):249-50.

4. Lancet T. Mental health: time to invest in quality. Lancet. 2020;396(10257):1045.

Cite this article : Hoekstra KA. Population Mental Health during the COVID-19 Pandemic: Experiences from a Drive-thru Testing Center. Int. J. Med. Public Health. 2021;11(3):168-9. 